\begin{tabular}{|c|l|}
\hline Title & Seasonal variation of tropospheric ozone in Indonesia revealed by 5-year ground-based observations \\
\hline Author(s) & $\begin{array}{l}\text { Fujiwara, Masatomo; Kita, Kazuy uki; Ogawa, Toshihiro; Kawakami, Shuji; Sano, Takuki; Komala, Ninong; Saraspriya, } \\
\text { Slamet; Suripto, Agus }\end{array}$ \\
\hline Citation & $\begin{array}{l}\text { Journal of Geophysical Research: Atmospheres, 105(D2), 1879-1888 } \\
\text { https:/doi.org/_0.1029/1999JD900916 }\end{array}$ \\
\hline Issue Date & 2000-01-27 \\
\hline Doc URL & http://hdl.handle.net/2115/64866 \\
\hline Rights & Copyright 2000 A merican Geophysical Union. \\
\hline Type & article \\
\hline File Information & Fujiwara_et_al-2000-Journal_of_Geophysical_Research_Atmospheres_(1984_2012).pdf \\
\hline
\end{tabular}

Instructions for use 


\title{
Seasonal variation of tropospheric ozone in Indonesia revealed by 5-year ground-based observations
}

\author{
Masatomo Fujiwara and Kazuyuki Kita \\ Department of Earth and Planetary Physics, Graduate School of Science, University of Tokyo \\ Toshihiro Ogawa, Shuji Kawakami, and Takuki Sano \\ Earth Observation Research Center, National Space Development Agency of Japan, Tokyo \\ Ninong Komala, Slamet Saraspriya, and Agus Suripto \\ Atmospheric Research and Development Center, Indonesian National Institute \\ of Aeronautics and Space, Bandung
}

\begin{abstract}
Regular ozonesonde observation and total ozone observation with the Brewer spectrophotometer have been conducted at Watukosek $\left(7.5^{\circ} \mathrm{S}, 112.6^{\circ} \mathrm{E}\right)$, Indonesia, since 1993. Three seasons are recognized for the vertical distribution of tropospheric ozone. (1) During the local wet season, between December and March, the ozone mixing ratio is nearly constant at $25 \mathrm{ppbv}$ throughout the troposphere. (2) During the transition season from wet to dry, between April and July, the mixing ratio is often enhanced in the uppermost troposphere. (3) During the local dry season, between August and November, the concentration is enhanced in the planetary boundary layer, and extensive forest fires in Indonesia associated with the strong El Niño events of 1994 and of 1997 have enhanced the ozone mixing ratio in the middle troposphere, the integrated tropospheric ozone, and the total ozone at Watukosek.
\end{abstract}

\section{Introduction}

The global budget of tropospheric ozone is primarily determined by transport from the stratosphere in the midlatitudes associated with synoptic-scale atmospheric waves, by photochemistry including socalled ozone precursor gases (nitric oxide (NO), carbon monoxide (CO), and hydrocarbons) emitted mainly from the Earth's surface, and by dry deposition on the surface. However, quantitative understanding of each process still remains incomplete because the spatial and temporal variations of tropospheric ozone have not been fully observed yet. In the tropical region the amount of long-term in situ observation data is especially limited. Results of ozonesonde observations which continued for more than a year in the tropics are briefly reviewed below.

The longest ozonesonde records in the tropics have been obtained at Natal $\left(5.9^{\circ} \mathrm{S}, 35.2^{\circ} \mathrm{W}\right)$, Brazil, in South America since 1978 [e.g., Kirchhoff et al., 1991, 1996]. A 10-year result showed that the maximum concentration in the troposphere occurred in September-

Copyright 2000 by the American Geophysical Union.

Paper number 1999JD900916.

0148-0227/00/1999JD900916\$09.00
October when it is the end of the local dry season in central Brazil and central Africa [Kirchhoff et al., 1991]. Kirchhoff et al. [1991] considered that the maximum ozone originated from the biomass burning in both regions. Since 1990, soundings have been conducted at Brazzaville $\left(4^{\circ} \mathrm{S}, 15^{\circ} \mathrm{E}\right)$, Congo, in central Africa [Cros et al., 1992; Nganga et al., 1996], and at Ascension Island $\left(8^{\circ} \mathrm{S}, 14^{\circ} \mathrm{W}\right)$ in the Atlantic Ocean [e.g., Cros et al., 1992; Diab et al., 1996]. The results at both stations showed that the seasonal maximum abundance of tropospheric ozone occurred in September, the active burning season in Africa [Cros et al., 1992]. There is a report of a 1-year result at Reunion island $\left(21^{\circ} \mathrm{S}, 55^{\circ} \mathrm{E}\right)$, near Madagascar [Baldy et al., 1996]. In the central Pacific Ocean a station at Hilo $\left(19.7^{\circ} \mathrm{N}, 155.1^{\circ} \mathrm{W}\right)$ has maintained records since 1985 [e.g., Oltmans et al., 1996]. In tropical east Asia, ozonesonde observation has been conducted at Watukosek $\left(7.5^{\circ} \mathrm{S}, 112.6^{\circ} \mathrm{E}\right)$, Indonesia, since 1992 (regularly since May 1993) [Komala et al., 1996; Komala, 1996; Fujiwara et al., 1998a, b, 1999]. The results obtained at this site are discussed in this paper. Regular ozonesonde observations have also been performed at Petaling Jaya $\left(3.1^{\circ} \mathrm{N}, 101.7^{\circ} \mathrm{E}\right)$, Malaysia, since 1992 [Tsuruta et al., 1997] and at Penang $\left(5.2^{\circ} \mathrm{N}\right.$, $100^{\circ} \mathrm{E}$ ), Malaysia, since 1994 [ Ilyas et al., 1997]. In India a long record (since 1969) exists at Trivandrum $\left(8.9^{\circ} \mathrm{N}, 76.6^{\circ} \mathrm{E}\right)$ with some data gaps (G. S. Prakasa 
Rao, India Meteorological Department, private communication, 1998).

As discussed in most of the above papers, biomass burning in the tropics such as forest and savanna fires is recognized to make the most significant impact on tropical tropospheric ozone because it is a strong source of ozone precursor gases [Crutzen and Andreae, 1990; Levine, 1991]. Several aircraft measurements obtained elevated ozone concentrations (from 40 to $160 \mathrm{ppbv}$ ) which correlated with enhancements of the precursors and aerosols emitted from the burning over or near Brazil [e.g., Crutzen et al., 1985; Delany et al., 1985; Browell et al., 1988; Andreae et al., 1994], over tropical Africa [e.g., Marenco et al., 1990; Andreae et al., 1992], and over the Atlantic including South America and Africa [e.g., Lindesay et al., 1996; Fishman et al., 1996]. Satellite data analyses visualized the tropospheric ozone variation in the tropics, suggesting a global-scale influence of biomass burning especially over the Atlantic region [e.g., Fishman et al., 1990; Ziemke et al., 1996, 1998; Hudson and Thompson, 1998]. Biomass burning is most intense in the tropics during the AugustOctober period in the southern hemispheric part of South America, Africa, and Asia including northern Australia but is observed somewhere within $60^{\circ} \mathrm{N}$ and $40^{\circ} \mathrm{S}$ throughout the year [e.g., Andreae, 1993; Husar et al., 1997]. However, in situ observational studies on atmospheric chemistry affected by the burning in tropical east Asia are still quite sparse [e.g., Fujiwara et al., 1998a, 1999], though, as reviewed above, measurements have been made rather intensively over South America, the Atlantic, and Africa.

The contribution of ozone transport from the midlatitudes to the tropics has been discussed, though systematic studies are quite limited. Loring et al. [1996] and Baray et al. [1998] discussed possible influences of tropopause foldings near the subtropical jet stream on the tropical tropospheric ozone concentrations. Some observations showed that the anthropogenic emissions from the Asian continent (so-called Asian outflow) influenced the atmospheric composition over the tropical Pacific [e.g., Oltmans et al., 1996; Gregory et al., 1997; Jaffe et al., 1997]. However, ozone transport from the tropical stratosphere (in other words, ozone transport due to stratosphere-troposphere exchange (STE) in the tropics) has not been fully discussed so far. This may be partly because there are relatively few ozone observations in this region and partly because of a historical reason.

Since Brewer [1949], the "cold trap" or dehydration mechanism at the tropical tropopause has been the key for the tropical STE process, and the tropical tropopause has been regarded as the region where the tropospheric air is transported upward to the stratosphere. On the basis of the monthly averaged temperature on the 100-hPa surface in the tropics, Newell and Gould-Stewart [1981] showed that the regions where the tropospheric air enters into the tropical lower strato- sphere would be limited seasonally and longitudinally, though, quite recently, Dessler [1998] questioned this hypothesis. Danielsen [1982] focused on the role of cumulonimbus clouds and proposed a dehydration model. Since his paper, cumulonimbus penetration into the lowermost stratosphere has been considered as the most efficient mechanism for the tropical STE. Focusing on the role of the tropical convective activity, intensive aircraft observations have been conducted at Panama (see the special issue in Geophysical Research Letters, 9(6), 599-624, 1982) and at Darwin, northern Australia [e.g., Russell et al., 1993; Danielsen, 1993]. However, Danielsen's mechanism has not been verified yet; sometimes deep convections hydrated rather than dehydrated the lowermost stratosphere. In a recent review of STE by Holton et al. [1995] the idea of Danielsen [1982] is presented as a basic hypothesis, but the detailed mechanism is still unclear.

Unlike the extratropical STE, in which the central role of synoptic-scale atmospheric waves is widely recognized, the role of waves around the tropical tropopause has been paid little attention in terms of STE, though the existence of various modes of equatorial waves has been known since the 1960s [e.g., Matsuno, 1966; Yanai and Maruyama, 1966; Wallace and Kousky, 1968]. Relatively recently, Tsuda et al. [1994] pointed out a possible role of the equatorial Kelvin wave, which is one of the equatorially trapped planetary-scale gravity waves [e.g., Andrews et al., 1987], in the tropical STE for the first time, on the basis of results of one-month intensive radiosonde observation at Watukosek. Tsuda et al. found that a Kelvin wave with a period of 20 days had greatly modified the structure of the tropopause; the temperature variation during the passage of this wave was between $185 \mathrm{~K}$ and $193 \mathrm{~K}$, and the tropopause height variation was between $15.6 \mathrm{~km}$ and $18.0 \mathrm{~km}$. Fujiwara et al. [1998b] confirmed the Kelvin wave's role in the tropical STE; they investigated a case of upper tropospheric ozone enhancement through intensive observation with ozonesondes and radiosondes in Indonesia, concluding that the Kelvin wave activity including its breaking around the tropopause caused ozone transport from the stratosphere into the troposphere.

In this paper, the seasonal variability of tropospheric ozone in Indonesia is investigated by using 5-year ground-based data. The controlling processes for the variations are then discussed, and the major role of the photochemical production from biomass burning emissions in Indonesia, especially during El Niño events, is suggested. The upper tropospheric ozone variation is also described.

\section{Ozone Observations in Indonesia}

Regular ozonesonde observation and total ozone observation with the Brewer spectrophotometer have been conducted at Watukosek $\left(7.5^{\circ} \mathrm{S}, 112.6^{\circ} \mathrm{E} ; 50 \mathrm{~m}\right.$ above the mean sea level), east Java, Indonesia, since 1993. 
In east Java the seasonal variation of weather is determined by the Asian monsoon. Generally, the local dry season is between July and October, and the local wet season is between December and March. The Watukosek observatory is located on the slope of a low hill surrounded by large-scale fields of sugarcane, rice, and so on, as well as roads with moderate traffic.

\subsection{Ozonesonde Observation}

Vertical distributions of atmospheric ozone, temperature, pressure, and horizontal wind were measured with electrochemical carbon-iodine ozonesondes (Meisei RSII-KC79D) with the TOTEX TX3000-type balloons and a tracking system. The data sampling intervals are $2 \mathrm{~s}$ for wind, $4 \mathrm{~s}$ for ozone, and $16 \mathrm{~s}$ for the other parameters with an ascending speed of $\sim 5 \mathrm{~m} \mathrm{~s}^{-1}$. In this paper, the vertical resolution is set to $200 \mathrm{~m}$ by linear interpolation. The total ozone correction with the Brewer measurement was not applied to the data used here.

There were a total of 144 ozonesonde soundings between May 1993 and April 1998. Most of the launches were made at 1000 LST. In this paper, we use 112 profiles in which ozone concentrations were successfully measured at least up to $16.6-\mathrm{km}$ altitude, which is the average tropopause altitude defined by the temperature minimum $\left(194.7 \mathrm{~K}\right.$ or $-78.5^{\circ} \mathrm{C}$ on the average). On the average, the maximum ozone partial pressure is $\mathbf{1 2 9}$ nbar at $26.6 \mathrm{~km}$, and the maximum ozone mixing ratio is $8.25 \mathrm{ppmv}$ at $29.6 \mathrm{~km}$ (Figure 1). Note the large variability of ozone in the middle stratosphere (above $25 \mathrm{~km}$ ) in Figure 1. Because satellite observations have shown that the amplitudes of annual and quasi-biennial variations at $30-\mathrm{km}$ altitude in the tropics are both 1 ppmv [e.g., McPeters et al., 1984; Hasebe, 1994], more than half of the obtained variability in the middle stratosphere may be caused artificially by the following three factors: (1) the calibration of pump flow rate which might not be well validated for very low pressures; (2) bubbling of remaining air in the carbon electrode into the potassium iodide solution, though to avoid such a case all the ozonesondes were situated in a low-pressure chamber for an hour before each flight to promote degassing; and (3) underestimation of ozone concentration due to unstable air sampling pump performance caused by shorter lifetime of the battery than expected after going through the very cold tropopause. However, this paper concentrates on the tropospheric profiles, so that these factors have little influence on the analyses and discussions.

\subsection{Total Ozone Observation With the Brewer Spectrophotometer}

An MKIV-type Brewer spectrophotometer has been used to measure total ozone at Watukosek since November 1993. Before being sent to Indonesia, the instrument was operated side by side with a Dobson spectrophotometer at Tsukuba/Tateno $\left(36^{\circ} \mathrm{N}, 140^{\circ} \mathrm{E}\right)$, Japan, to confirm that the Brewer measurement was identical to the Dobson one within $\pm 5 \%$ with a time difference of observations of $<30 \mathrm{~min}$.

Observations were conducted every hour in the daytime. The daily representative values of total ozone are derived by considering the standard deviation of each observation and the solar zenith angle. The standard deviation will be large when the intensities of solar ra-

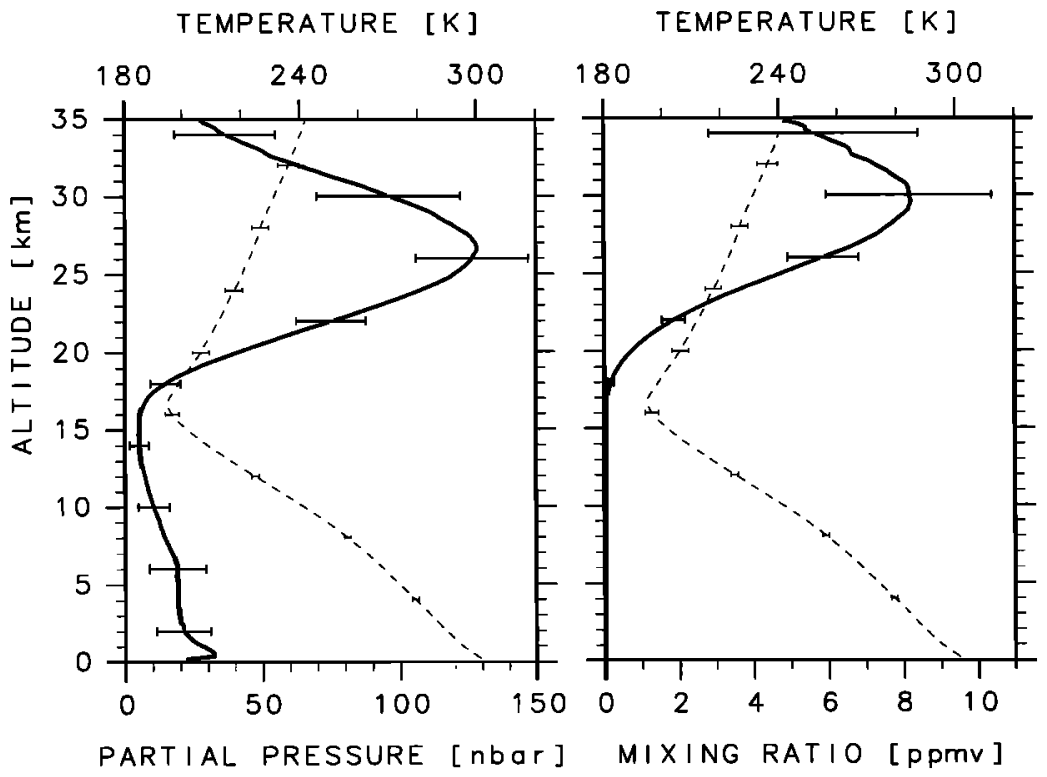

Figure 1. Average vertical profiles of (left) ozone partial pressure and (right) ozone volume mixing ratio together with the temperature profiles (dashed curves) between May 1993 and April 1998 (with 112 profiles). Their standard deviations, which indicate the variability, are also shown by horizontal lines at some representative altitudes. 
diation change because of clouds during a set of the observation ( $140 \mathrm{~s})$, so that data with a large standard deviation should be excluded. In this paper, the critical value of 5 Dobson units (DU) was adopted according to the results of the test operation at Tsukuba/Tateno. When the solar zenith angle is large, the UV radiation becomes much weaker than the visible one; in such a case, the visible light may make the quality of the UV light measurement worse. Considering these factors, the daily representative values of total ozone were obtained for this paper as follows: The raw data obtained at small solar zenith angles between 1030 and 1330 LST with the standard deviation of $<5 \mathrm{DU}$ were corrected according to the daily quartz-halogen lamp test, which monitors the sensitivity of the instrument, and were averaged.

The numbers of the days when the Brewer total ozone observation was conducted are 540 between November 1993 and July 1995 and 526 between September 1996 and April 1998. Between November 1995 and September 1996 the observation was not conducted for repair and recalibration of the instrument, whose $\mathrm{NiSO}_{4}$ filter was deteriorated probably because of high humidity.

\section{Results and Discussion}

Figure 2 shows the average vertical distributions of tropospheric ozone and temperature with their standard deviations between May 1993 and April 1998. The average ozone mixing ratio between the surface and 15 $\mathrm{km}$ was in the range of $25-35 \mathrm{ppbv}$ with two small maxima of $35 \mathrm{ppbv}$ at $0.5 \mathrm{~km}$ and $40 \mathrm{ppbv}$ at $7 \mathrm{~km}$. The standard deviation, which indicates the variability during the period, was in the range of $\pm(10-15)$ ppbv except for that in the uppermost troposphere above 15 $\mathrm{km}$ where there is a large variability of $\pm 30 \mathrm{ppbv}$. On the other hand, the variability of temperature was much smaller, i.e., $\pm 1 \mathrm{~K}$ throughout the troposphere and \pm 1.5 $\mathrm{K}$ in the lower stratosphere. Time series of ozone mixing ratio averaged in three representative altitude regions are shown in Figure 3. The choice of the regions is based on the three features in Figure 2. The average ozone concentration in the upper troposphere, 12-16 $\mathrm{km}$ (Figure 3a), was mostly less than 50 ppbv but sometimes showed significant enhancement of $>50$ ppbv during the April-July period of 1993-1995 and during the October-December period of 1997. The concentration in the middle troposphere, $5-10 \mathrm{~km}$ (Figure $3 \mathrm{~b}$ ), showed a significant increase during the August-November periods of 1994 and of 1997 when extensive forest fires were reported in Indonesia [Fujiwara et al., 1999]. The concentration in the planetary boundary layer (PBL), altitude region of 0.2-2 km [cf. Hashiguchi et al., 1996], showed a clear annual cycle with its maximum during the August-November period (Figure 3c).

Figure 3 also indicates that during the 1997 forest fire event the ozone concentration was higher in the higher layers (60-100 ppbv at 5-10 km and at 12-16 $\mathrm{km})$ than in the lower layers $(40-60 \mathrm{ppbv}$ at $0.5-2 \mathrm{~km})$.

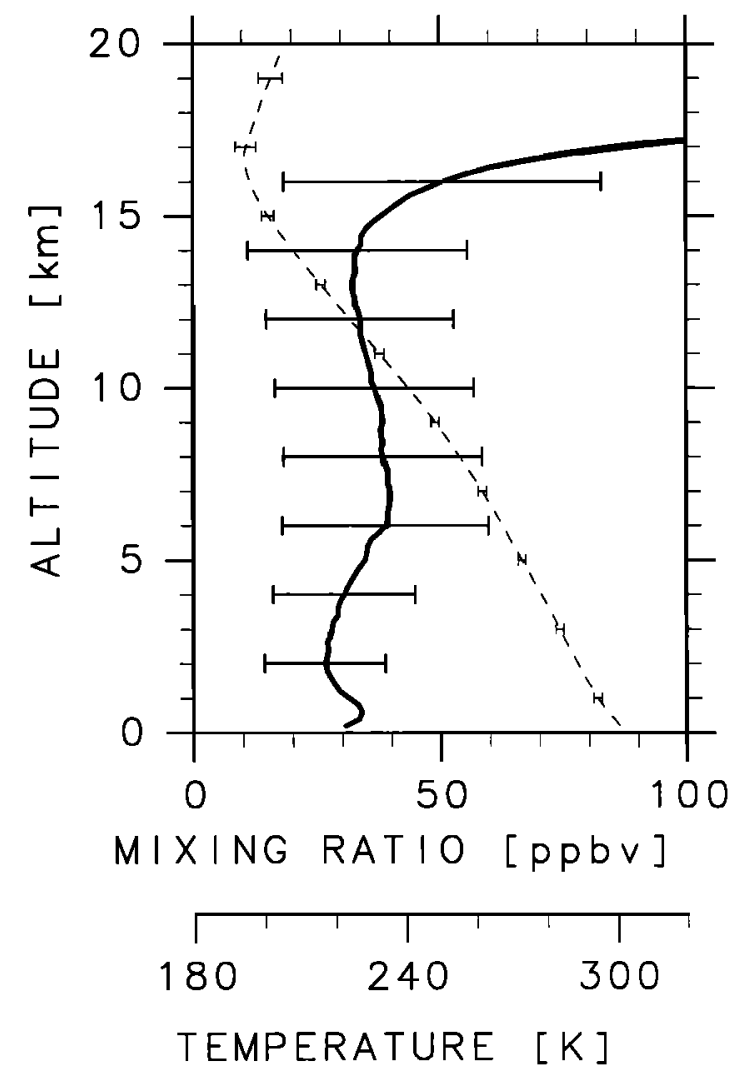

Figure 2. Same as Figure 1 but for ozone mixing ratio in the $0-20-\mathrm{km}$ altitude region.

This is mainly because the major burning regions were not in Java island but in Sumatra and Borneo islands; the ozone-enriched air masses in the higher layers at Watukosek were transported horizontally from the west as noted by Fujiwara et al. [1999]. Figure 4 visualizes the temporal variation of upper tropospheric ozone during the 1997 event. We have conducted once-per-week observation between October and December 1997. The ozone concentration in the upper troposphere demonstrated a systematic variation with a period of three or four weeks. The ozone enhancements in November and in December were accompanied by a positive vertical gradient of ozone just below the tropopause, suggesting a possibility that stratospheric transports were superimposed on the burning-originating ozone enhancements in this altitude region.

Figure 5 represents the average tropospheric profiles of ozone and temperature with their standard deviations for the three seasons, December-March, AprilJuly, and August-November. The data between July 1997 and April 1998 are excluded in these plots because this period corresponded to a very strong El Niño event and pronounced enhancements of tropospheric ozone were observed as previously discussed.

Figure 5a shows the average profiles between December and March, when it is the local wet season. The ozone mixing ratio is nearly constant at $\sim 25 \mathrm{ppbv}$, and the standard deviation is $<10 \mathrm{ppbv}$ throughout the troposphere; these values are the lowest ones among the 


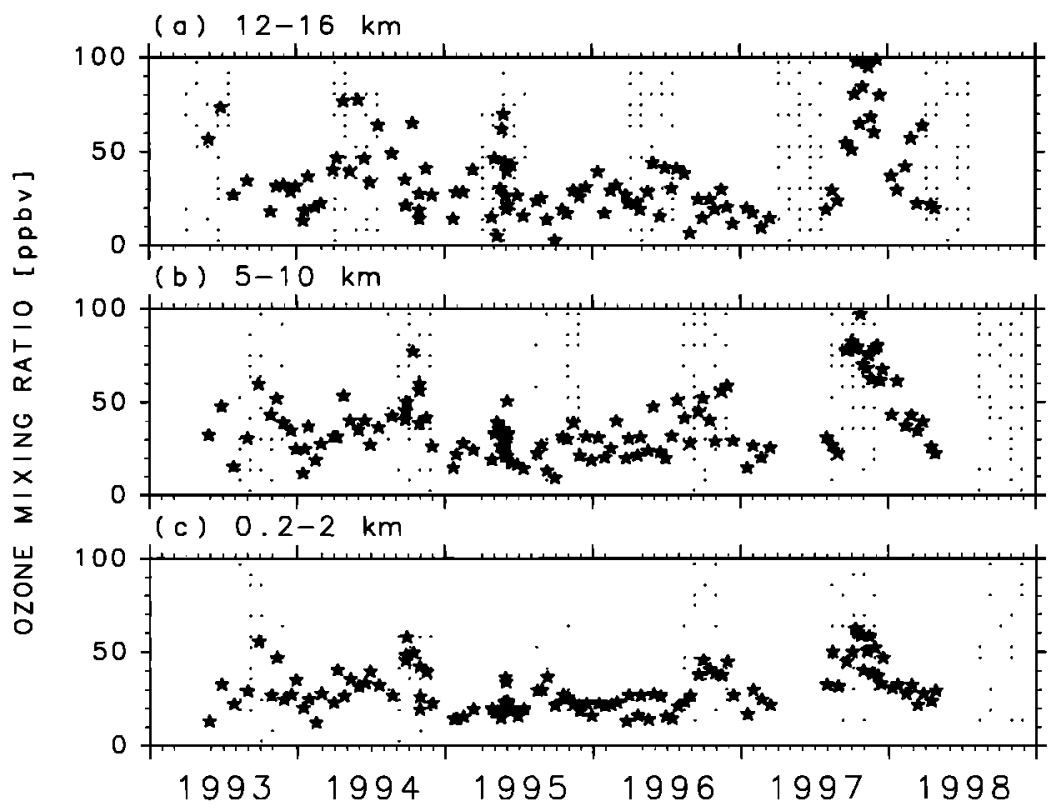

Figure 3. Time series of ozone mixing ratio averaged in (a) $12-16 \mathrm{~km}$, (b) $5-10 \mathrm{~km}$, and (c) $0.2-2$ $\mathrm{km}$, between May 1993 and April 1998. The periods of April-July are shaded in Figure 3a, and the periods of August-November are shaded in Figures $3 \mathrm{~b}$ and $3 \mathrm{c}$.

three seasons. This type of ozone profile is the basic one at this station as noted by Komala et al. [1996]. Results of ozonesonde observation campaigns in the western Pacific showed basically similar characteristics [Kley et al., 1996]. However, the average profiles at Manaus, Brazil [Kirchhoff et al., 1990, Figure 9], at Natal, Brazil [Kirchhoff et al., 1991, Figure 7], and at Hilo, Hawaii [Oltmans et al., 1996, Figure 6] exhibited larger val- ues of more than $30-40 \mathrm{ppbv}$ in the free troposphere even during the non-burning seasons. Note that the ozone concentration of $20-25$ ppbv near the surface at Watukosek is, in contrast, higher than those of 10-25 ppbv with a positive vertical gradient at the above three tropical stations. This may be attributed to the difference in the surface conditions. Among the stations referred to here, Watukosek is probably the only station

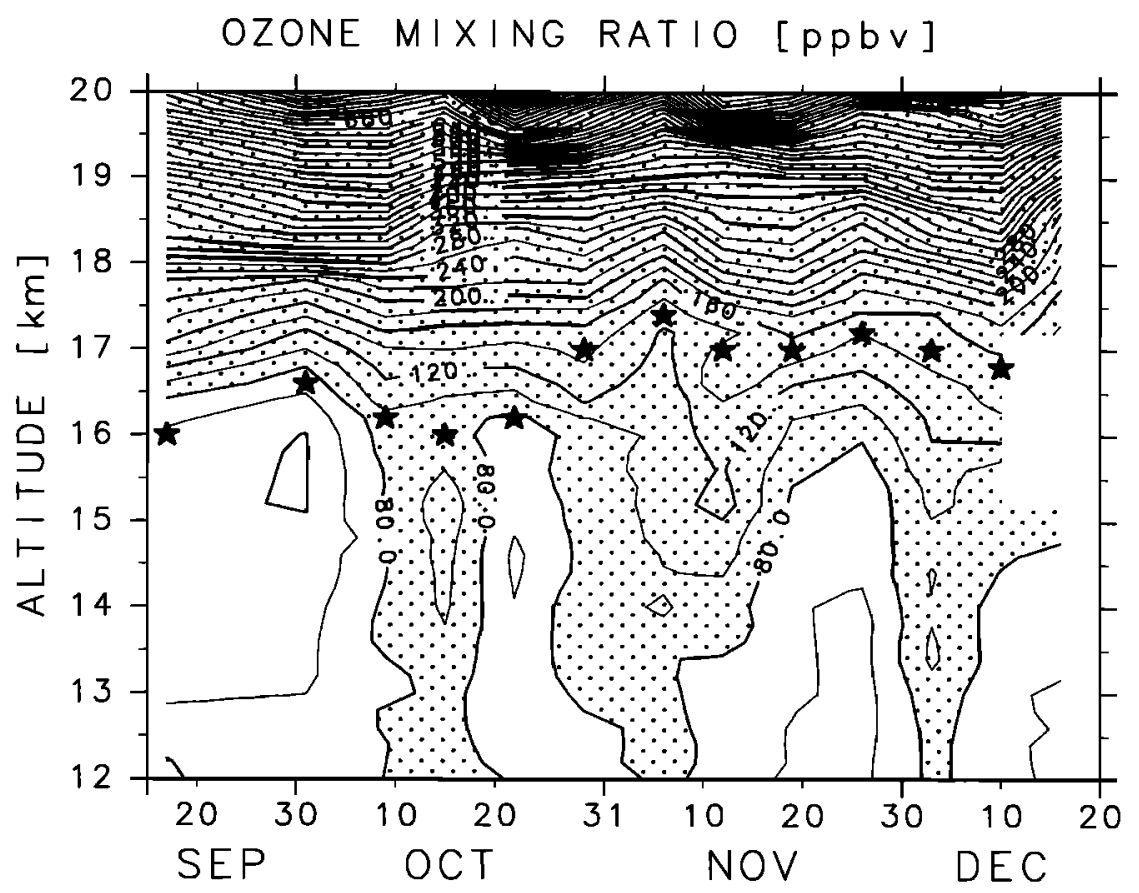

Figure 4. Time-altitude cross section of ozone mixing ratio in the $12-20 \mathrm{~km}$ altitude region from September to December 1997. The locations of the tropopause are indicated by stars. The region of $>80 \mathrm{ppbv}$ is shaded. 


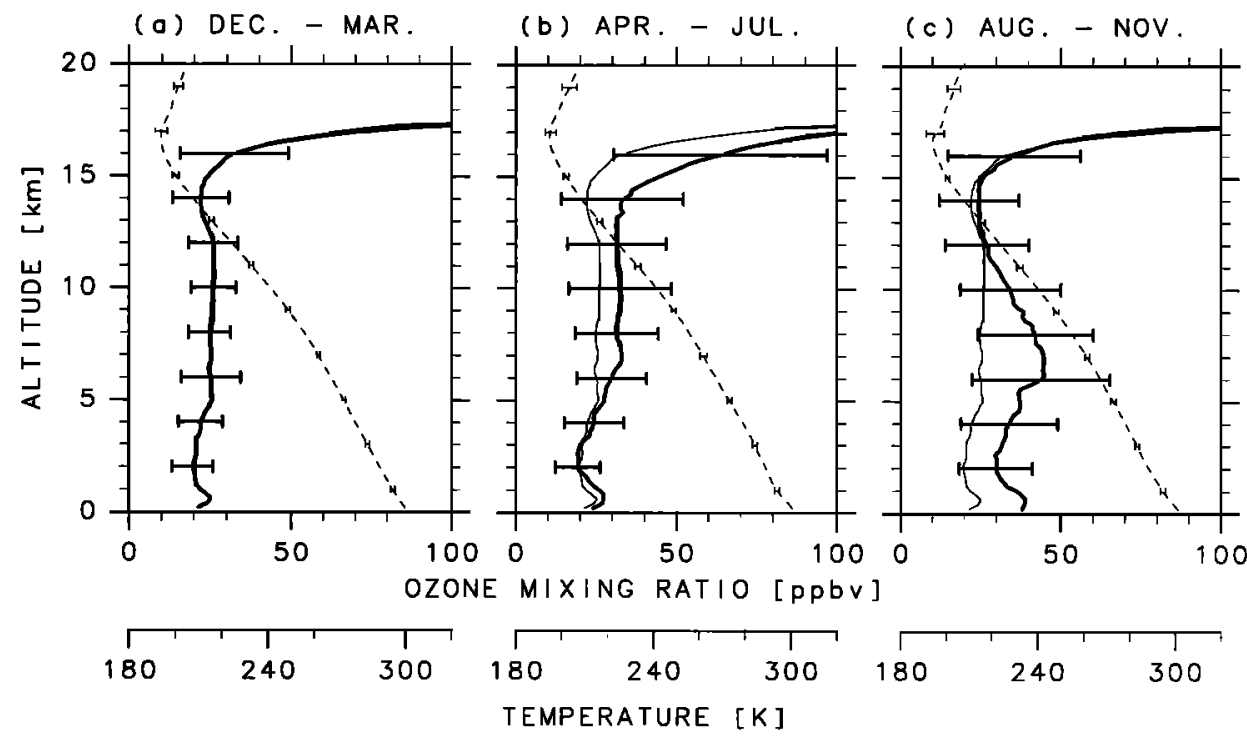

Figure 5. Same as Figure 2 but averaged in (a) December-March (25 profiles), (b) April-July (32 profiles), and (c) August-November (31 profiles), between May 1993 and March 1997. Thin curves in Figures $5 \mathrm{~b}$ and $5 \mathrm{c}$ indicate the average ozone profile in Figure $5 \mathrm{a}$.

that is strongly influenced by photochemical production of ozone in the PBL related to man's activity even in this season.

Figure 5b shows the average profiles between April and July, the transition period from the wet season to the dry season in east Java. The ozone concentration in the middle and upper troposphere up to $14 \mathrm{~km}$ is slightly larger ( $\sim 30 \mathrm{ppbv})$ with slightly larger variability $( \pm 15 \mathrm{ppbv})$ than those between December and March. Above $14 \mathrm{~km}$, however, the average profile has a positive vertical gradient of $\sim 2 \times 10^{-2}$ ppbv $\mathrm{m}^{-1}$ with very large variability of $\pm 30 \mathrm{ppbv}$, though the tropopause altitude shows no distinct difference from those in other seasons. Results of ozonesonde observations at other tropical sites showed similar positive vertical gradients or large variability in the average profiles in the uppermost troposphere [e.g., Kirchhoff et al., 1990, Figure 9; Kirchhoff et al., 1991, Figure 7; and Oltmans et al., 1996, Figure 6]. Cros et al. [1992], Diab et al. [1996], Baldy et al. [1996], Kley et al. [1996], and Weller et al. [1996] also showed some cases in which ozone enhancements occurred in the tropical upper troposphere. The April-July period is the transition from the local wet season to the dry season in Java, and no significant ozone increase related to biomass burning is observed during this period. Lightning may produce nitrogen oxides $\left(\mathrm{NO}_{x}\right)$ in the upper troposphere to promote the photochemical ozone production [e.g., Pickering et al., 1993], but the ozone enhancement is often observed during the transition season, not during the wet season when the lightning activity reaches its maximum. Therefore the transport from the stratosphere should be considered to explain the upper tropospheric ozone enhancement. If ozone-enriched air masses associated with the tropopause foldings in the midlatitudes were transported into the tropical region, it would be observed primarily at $200-500-\mathrm{hPa}$ level $(5-11-\mathrm{km}$ altitude) in the tropics because the tropopause in the midlatitudes is situated at $200-300 \mathrm{hPa}(8-11 \mathrm{~km})$ and the corresponding isentropic surfaces are found around the same altitude or lower in the tropics [e.g., Chen, 1995, Figure 1]. Chen [1995] suggested another type of transport from the midlatitude stratosphere to the tropical troposphere, arguing that the monsoon circulations in the summer hemisphere would result in active stratosphere-troposphere exchange on the 350$\mathrm{K}$ isentropic surface. Another candidate is the transport from the tropical stratosphere: Fujiwara et al. [1998b] investigated a case of the upper tropospheric cnhancement by intensive observation with ozonesondes and radiosondes in Indonesia and concluded that the equatorial Kelvin wave activity around the tropopause had caused ozone transport from the tropical stratosphere. The transport related to the equatorial gravity waves may be the key process to explain the upper tropospheric ozone enhancement at Watukosek, but all the photochemical and dynamical processes cited above should be investigated comprehensively before we obtain the conclusion.

Figure $5 \mathrm{c}$ shows the average profiles between August and November near the end of the local dry season. The ozone mixing ratios are enhanced up to $40 \mathrm{ppbv}$ in the PBL and up to $45 \mathrm{ppbv}$ in the middle troposphere. Note that the average concentration in the upper troposphere is low ( $25 \mathrm{ppbv})$ in this season except for 1997. Because this season corresponds to the burning period in east Java, the enhancement in the PBL, which is observed every year as seen in Figure $3 c$, can be attributed to the local burnings around the observatory. It should be noted that most of the ozonesondes were launched at 


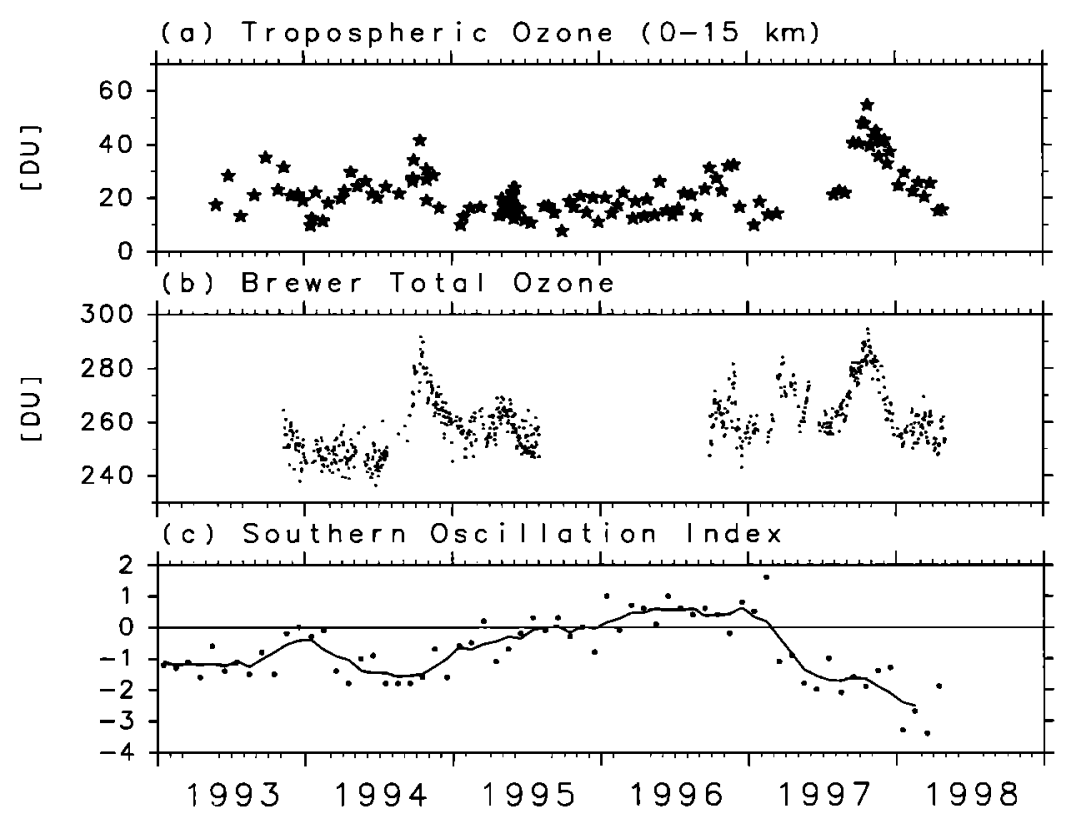

Figure 6. Time series of (a) the integrated tropospheric ozone amount between surface and $15 \mathrm{~km}$ calculated from the ozonesonde data, (b) the total ozone measured with the Brewer spectrophotometer, and (c) the Southern Oscillation Index (SOI) with its five-month running mean (curve), between 1993 and April 1998.

1000 LST and that, as noted by Komala et al. [1996], the surface ozone concentration at this site has a clear diurnal variation with its maximum before noon independent of season. On the other hand, the enhancement in the middle troposphere, which is not observed every year (Figure $3 \mathrm{~b}$ ), can be caused by regional-scale burnings associated with the El Niño events.

Thouret et al. [1998] presented the Measurement of Ozone and Water Vapor by Airbus In-Service Aircraft (MOZAIC) results, ozone seasonal profiles at 9-12 km in the Northern Hemisphere. Their Figure 11, in the plot for southeastern Asia, shows basically the same concentration values as the Watukosek results. But the plot also indicates that the maximum concentration appears in boreal spring, not in boreal autumn. This is probably because their sampling points were located in the northern hemispheric part of tropical east Asia where the local dry season, i.e., biomass burning, occurs in boreal winter-spring.

Figure 6 shows the time series of the integrated tropospheric ozone obtained from the ozonesonde data, total ozone from the Brewer measurement, and the Southern Oscillation Index (SOI) between 1993 and April 1998. The SOI data are available from Climate Prediction Center, National Oceanic and Atmospheric Administration (CPC/NOAA) (Washington, D. C.; anonymous $\mathrm{ftp}$ to 140.90 .50 .22 ). Some of this information is available from $U . S$. Department of Commerce [1998]. The tropospheric ozone was within the range of 10-30 DU for most of the observation period but showed enhancements up to $40 \mathrm{DU}$ in October 1994 and up to $55 \mathrm{DU}$ in October 1997. The total ozone was mostly within 250 to $260 \mathrm{DU}$ but also showed enhancements up to $290 \mathrm{DU}$ in the same periods. As comprehensively discussed by Fujiwara et al. [1999], these two enhancements were attributed to the extensive forest fires in Indonesia (especially in Sumatra and Borneo islands) due to very sparse precipitation associated with the El Niño events as indicated by large negative values of SOI. The tropospheric ozone enhancement in Indonesia and its relation to SOI since 1979 are presented by K. Kita et al. (Enhancement of total ozone over Indonesian region and its relation to the El Niño-Southern Oscillation, submitted to Atmospheric Environment, 1999) by using the Total Ozone Mapping Spectrometer (TOMS) data. During the February-June period of 1997 the total ozone at Watukosek also showed some spikes up to 275-280 DU (Figure 6b). A TOMS data analysis showed a regional-scale enhancement around the Indonesian region; its horizontal extent was similar to those observed in the September-October periods of 1994 and of 1997. Because this season corresponds to the end of the local dry season in the northern hemispheric part of the tropical east Asia, biomass burning there at that time may cause tropospheric ozone enhancements. However, the quality of ozonesonde data in this period was not good, so we could not discuss whether these enhancements had originated in the troposphere or in the stratosphere by using our ground-based results.

\section{Summary}

The seasonal variation of tropospheric ozone at Watukosek, Indonesia, has been presented and dis- 
cussed on the basis of the results from the 5-year ozonesonde and Brewer measurements between 1993 and 1998. The average ozone mixing ratio between the surface and $15 \mathrm{~km}$ was in the range of $25-35 \mathrm{ppbv}$, and the variability inferred from the standard deviation was in the range of $\pm(10-15)$ ppbv.

Three seasons have been recognized for the vertical distribution of tropospheric ozone. (1) During the local wet season, between December and March, the ozone mixing ratio has been nearly constant at $\sim 25( \pm 10)$ ppbv throughout the troposphere. (2) During the transition season from wet to dry, between April and July, the average ozone profile has basically exhibited similar features to season 1 , but above $14 \mathrm{~km}$ the average profile has a positive vertical gradient with very large variability of \pm 30 ppbv. (3) During the local dry season, between August and November, the ozone concentration (at $1000 \mathrm{LST}$ ) has been enhanced in the PBL mainly because of the local biomass burnings. In association with season 3 , the concentrations in the middle troposphere also showed significant increases in this season in 1994 and in 1997.

Temporal variations of the integrated tropospheric ozone and total ozone have been shown along with that of SOI. The tropospheric ozone was mostly 10-30 DU but exhibited enhancements up to $40 \mathrm{DU}$ in October 1994 and up to $55 \mathrm{DU}$ in October 1997. The total ozone also exhibited enhancements from the bottom level of $250-260 \mathrm{DU}$ up to $290 \mathrm{DU}$ in the same periods. Regional-scale burnings, i.e., extensive forest fires in Indonesia associated with the El Niño events, enhanced the ozone mixing ratios in the middle troposphere, the integrated tropospheric ozone, and the total ozone at Watukosek during 1994 and 1997. These cases have been already discussed in detail by Fujiwara et al. [1999].

The upper tropospheric ozone enhancement often observed during the April-July period needs further, comprehensive analyses. The seasonality of the phenomenon may exclude the possibility of photochemical processes such as biomass burning and lightning as the primary cause. Therefore the transports from the stratosphere associated with the tropopause foldings in the midlatitudes, summer monsoon circulations, and equatorial gravity waves are the important candidates.

Acknowledgments. The authors thank N. Iwagami and two anonymous reviewers for their useful comments and suggestions. The figures were produced with the GFDDENNOU Library. M.F. was supported by research fellowships of the Japan Society for the Promotion of Science for Young Scientists.

\section{References}

Andreae, M. O., Global distribution of fires seen from space, Eos Trans. AGU, 74, 129 and 135, 1993.

Andreae, M. O., A. Chapuis, B. Cros, J. Fontan, G. Helas, C. Justice, Y. J. Kaufman, A. Minga, and D. Nganga,
Ozone and aitken nuclei over equatorial Africa: Airborne observations during DECAFE 88, J. Geophys. Res., 97, 6137-6148, 1992.

Andreae, M. O., B. E. Anderson, D. R. Blake, J. D. Bradshaw, J. E. Collins, G. L. Gregory, G. W. Sachse, and M. C. Shipham, Influence of plumes from biomass burning on atmospheric chemistry over the equatorial and tropical South Atlantic during CITE 3, J. Geophys. Res., 99, 12,793-12,808, 1994.

Andrews, D. G., J. R. Holton, and C. B. Leovy, Middle Atmosphere Dynamics, 489 pp., Academic, San Diego, Calif., 1987.

Baldy, S., G. Ancellet, M. Bessafi, A. Badr, and D. L. S. Luk, Field observations of the vertical distribution of tropospheric ozone at the island of Reunion (southern tropics), J. Geophys. Res., 101, 23,835-23,849, 1996.

Baray, J. L., G. Ancellet, F. G. Taupin, M. Bessafi, S. Baldy, and P. Keckhut, Subtropical tropopause break as a possible stratospheric source of ozone in the tropical troposphere, J. Atmos. Sol. Terr. Phys., 60, 27-36, 1998.

Brewer, A. W., Evidence for a world circulation provided by the measurements of helium and water vapour distribution in the stratosphere, Q. J. R. Meteorol. Soc., 75, 351-363, 1949.

Browell, E. V., G. L. Gregory, R. C. Harriss, and V. W. J. H. Kirchhoff, Tropospheric ozone and aerosol distributions across the Amazon Basin, J. Geophys. Res., 93, 1431$1451,1988$.

Chen, P., Isentropic cross-tropopause mass exchange in the extratropics, J. Geophys. Res., 100, 16,661-16,673, 1995.

Cros, B., D. Nganga, A. Minga, J. Fishman, and V. Brackett, Distribution of tropospheric ozone at Brazzaville, Congo, determined from ozonesonde measurements, $J$. Geophys. Res., 97, 12,869-12,875, 1992.

Crutzen, P. J., and M. O. Andreae, Biomass burning in the tropics: Impact on atmospheric chemistry and biogeochemical cycle, Science, 250, 1669-1678, 1990.

Crutzen, P. J., A. C. Delany, J. Greenberg, P. Haagenson, L. Heidt, R. Lueb, W. Pollock, W. Seiler, A. Wartburg, and P. Zimmerman, Tropospheric chemical composition measurements in Brazil during the dry season, J. Atmos. Chem., 2, 233-256, 1985.

Danielsen, E. F., A dehydration mechanism for the stratosphere, Geophys. Res. Lett., 9, 605-608, 1982.

Danielsen, E. F., In situ evidence of rapid, vertical, irreversible transport of lower tropospheric air into the lower tropical stratosphere by convective cloud turrets and by large-scale upwelling in tropical cyclones, $J$. Geophys. Res., 98, 8665-8681, 1993.

Delany, A. C., P. Haagensen, S. Walters, and A. F. Wartburg, Photochemically produced ozone in the emission from large-scale tropical vegetation fires, $J$. Geophys. Res., 90, 2425-2429, 1985.

Dessler, A. E., A reexamination of the "stratospheric fountain" hypothesis, Geophys. Res. Lett., 25, 4165-4168, 1998.

Diab, R. D., et al., Vertical ozone distribution over southern Africa and adjacent oceans during SAFARI-92, J. Geophys. Res., 101, 23,823-23,833, 1996.

Fishman, J., C. E. Watson, J. C. Larsen, and J. A. Logan, Distribution of tropospheric ozone determined from satellite data, J. Geophys. Res., 95, 3599-3617, 1990.

Fishman, J., J. M. Hoell Jr., R. D. Bendura, R. J. McNeal, and V. W. J. H. Kirchhoff, NASA GTE TRACE A Experiment (September-October 1992): Overview, J. Geophys. Res., 101, 23,865-23,879, 1996.

Fujiwara, M., K. Kita, T. Ogawa, N. Komala, S. Saraspriya, A. Suripto, and T. Sano, Total ozone enhancement in September and October 1994 in Indonesia, in Atmospheric 
Ozone, Vol. 1, edited by R. D. Bojkov and G. Visconti, pp. 363-366, 1998a.

Fujiwara, M., K. Kita, and T. Ogawa, Stratospheretroposphere exchange of ozone associated with the equatorial Kelvin wave as observed with ozonesondes and rawinsondes, J. Geophys. Res., 103, 19,173-19,182, 1998 b.

Fujiwara, M., K. Kita, S. Kawakami, T. Ogawa, N. Komala, S. Saraspriya, and A. Suripto, Tropospheric ozone enhancements during the Indonesian forest fire events in 1994 and in 1997 as revealed by ground-based observations, Geophys. Res. Lett., 26, 2417-2420, 1999.

Gregory, G. L., J. T. Merrill, M. C. Shipham, D. R. Blake, G. W. Sachse, and H. B. Singh, Chemical characteristics of tropospheric air over the Pacific Ocean as measured during PEM-West B: Relationship to Asian outflow and trajectory history, J. Geophys. Res., 102, 28,275-28,285, 1997.

Hasebe, F., Quasi-biennial oscillations of ozone and diabatic circulation in the equatorial stratosphere, J. Atmos. Sci., 51, 729-745, 1994.

Hashiguchi, H., S. Fukao, T. Tsuda, M. D. Yamanaka, S. W. B. Harijono, and H. Wiryosumarto, An overview of the planetary boundary layer observations over equatorial Indonesia with an L-Band clear-air doppler radar, Beitr. Phys. Atmos., 69, 13-25, 1996.

Holton, J. R., P. H. Haynes, M. E. McIntyre, A. R. Douglass, R. B. Rood, and L. Pfister, Stratosphere-troposphere exchange, Rev. Geophys., 33(4), 403-439, 1995.

Hudson, R. D., and A. M. Thompson, Tropical tropospheric ozone from total ozone mapping spectrometer by a modified residual method, J. Geophys. Res., 103, 22,12922,145, 1998.

Husar, R. B., J. M. Prospero, and L. L. Stowe, Characterization of tropospheric aerosols over the oceans with the NOAA advanced very high resolution radiometer optical thickness operational product, J. Geophys. Res., 102, 16,889-16,909, 1997.

Ilyas, M., K. P. Teh, and M. N. Ahmad, Tropospheric ozone measurements at the equator, paper presented at the International Symposium on Atmospheric Chemistry and Future Global Environment, International Global Atmospheric Chemistry, Int. Geosphere-Biosphere Prog., Nagoya, Japan, November 11-13, 1997.

Jaffe, D., A. Mahura, J. Kelley, J. Atkins, P. C. Novelli, and J. Merrill, Impact of Asian emissions on the remote North Pacific atmosphere: Interpretation of CO data from Shemya, Guam, Midway and Mauna Loa, J. Geophys. Res., 102, 28,627-28,635, 1997.

‘irchhoff, V. W. J. H., I. M. O. da Silva, and E. V. Browell, Ozone measurements in Amazonia: Dry season versus wet season, J. Geophys. Res., 95, 16,913-16,926, 1990.

Kirchhoff, V. W. J. H., R. A. Barnes, and A. L. Torres, Ozone climatology at Natal, Brazil, from in situ ozonesonde data, J. Geophys. Res., 96, 10,899-10,909, 1991.

Kirchhoff, V. W. J. H., J. R. Alves, F. R. da Silva, and J. Fishman, Observations of ozone concentrations in the Brazilian cerrado during the TRACE A field expedition, J. Geophys. Res., 101, 24,029-24,042, 1996.

Kley, D., P. J. Crutzen, H. G. J. Smit, H. Vömel, S. J. Oltmans, H. Grassl, and V. Ramanathan, Observations of near-zero ozone concentrations over the convective Pacific: Effects on air chemistry, Science, 274, 230-233, 1996.

Komala, N., Climatology of tropospheric ozone observed in Java island, Indonesia, Ph.D. thesis, 73 pp., Univ. of Tokyo, Tokyo, 1996.

Komala, N., S. Saraspriya, K. Kita, and T. Ogawa, Tropospheric ozone behavior observed in Indonesia, Atmos. Environ., 30, 1851-1856, 1996.
Levine, J. S. (Ed.), Global Biomass Burnıng: Atmospherıc, Climatic, and Biospheric Implications, 569 pp., MIT Press, Cambridge, Mass., 1991.

Lindesay, J. A., M. O. Andreae, J. G. Goldammer, G. Harris, H. J. Annegarn, M. Garstang, R. J. Scholes, and B. W. van Wilgen, International Geosphere-Biosphere Program/International Global Atmospheric Chemistry SAFARI-92 field experiment: Background and overview, J. Geophys. Res., 101, 23,521-23,530, 1996.

Loring, R. O., H. E. Fuelberg, J. Fishman, M. V. Watson, and E. V. Browell, Influence of a middle-latitude cyclone on tropospheric ozone distributions during a period of TRACE A, J. Geophys. Res., 101, 23,941-23,956, 1996.

Marenco, A., J. C. Medale, and S. Prieur, Study of tropospheric ozone in the tropical belt (Africa, America) from STRATOZ and TROPOZ campaigns, Atmos. Environ., Part A, 24, 2823-2834, 1990.

Matsuno, T., Quasi-geostrophic motions in the equatorial area, J. Meteorol. Soc. Jpn., 44, 25-43, 1966.

McPeters, R. D., D. F. Heath, and P. K. Bhartia, Average ozone profiles for 1979 from the NIMBUS 7 SBUV instrument, J. Geophys. Res., 89, 5199-5214, 1984.

Newell, R. E., and S. Gould-Stewart, A stratospheric fountain?, J. Atmos. Sci., 38, 2789-2796, 1981.

Nganga, D., A. Minga, B. Cros, C. B. Biona, J. Fishman, and $W$. B. Grant, The vertical distribution of ozone measured at Brazzaville, Congo during TRACE A, J. Geophys. Res., 101, 24,095-24,103, 1996.

Oltmans, S. J., D. J. Hofmann, J. A. Lathrop, J. M. Harris, W. D. Komhyr, and D. Kuniyuki, Tropospheric ozone during Mauna Loa Observatory Photochemistry Experiment 2 compared to long-term measurements from surface and ozonesonde observations, J. Geophys. Res., 101, 14,569-14,580, 1996.

Pickering, K. E., A. M. Thompson, W.-K. Tao, and T. L. Kucsera, Upper tropospheric ozone production following mesoscale convection during STEP/EMEX, J. Geophys. Res., 98, 8737-8749, 1993.

Russell, P. B., L. Pfister, and H. B. Selkirk, The tropical experiment of the Stratosphere-Troposphere Exchange Project (STEP): Science objectives, operations, and summary findings, J. Geophys. Res., 98, 8563-8589, 1993.

Thouret, V., A. Marenco, P. Nédélec, and C. Grouhel, Ozone climatologies at $9-12 \mathrm{~km}$ altitude as seen by the MOZAIC airborne program between September 1994 and August 1996, J. Geophys. Res., 103, 25,653-25,679, 1998.

Tsuda, T., Y. Murayama, H. Wiryosumarto, S. W. B. Harijono, and S. Kato, Radiosonde observations of equatorial atmosphere dynamics over Indonesia, 1, Equatorial waves and diurnal tides, J. Geophys. Res., 99, 10,491-10,505, 1994.

Tsuruta, H., S. Yonemura, L. C. Peng, and L. S. Fook, The increase of tropospheric ozone over Peninsular Malaysia by the 1994 forest fires in tropical East Asia, paper presented at the International Symposium on Atmospheric Chemistry and Future Global Environment, International Global Atmospheric Chemistry, Int. Geosphere-Biosphere Prog., Nagoya, Japan, November 11-13, 1997.

U. S. Department of Commerce, Climate Diagnostic Bulletin, Bull. 98/2, Washington, D. C., 1998.

Wallace, J. M., and V. E. Kousky, Observational evidence of Kelvin waves in the tropical stratosphere, J. Atmos. Sci., 25, 900-907, 1968.

Weller, R., R. Lilischkis, O. Schrems, R. Neuber, and S. Wessel, Vertical ozone distribution in the marine atmosphere over the central Atlantic Ocean $\left(56^{\circ} \mathrm{S}-50^{\circ} \mathrm{N}\right), J$. Geophys. Res., 101, 1387-1399, 1996.

Yanai, M., and T. Maruyama, Stratospheric wave distur- 
bances propagating over the equatorial Pacific, J. Meteorol. Soc. Jpn., 44, 291-294, 1966.

Ziemke, J. R., S. Chandra, A. M. Thompson, and D. P. McNamara, Zonal asymmetries in Southern Hemisphere column ozone: Implications of biomass burning, J. Geophys. Res., 101, 14,421-14,427, 1996.

Ziemke, J. R., S. Chandra, and P. K. Bhartia, Two new methods for deriving tropospheric column ozone from TOMS measurements: Assimilated UARS MLS/HALOE and convective-cloud differential techniques, $J$. Geophys. Res., 103, 22,115-22,127, 1998.

M. Fujiwara and K. Kita, Department of Earth and Planetary Physics, Graduate School of Science, University of
Tokyo, Tokyo 113-0033, Japan. (fuji@geoph.s.u-tokyo.ac.jp; kita@geoph.s.u-tokyo.ac.jp)

S. Kawakami, T. Ogawa, and T. Sano, Earth Observation Research Center, National Space and Development Agency of Japan, Tokyo 106, Japan. (kawakami@eorc.nasda.go.jp; t_ogawa@eorc.nasda.go.jp; sano@eorc.nasda.go.jp)

N. Komala, S. Saraspriya, and A. Suripto, Atmospheric Research and Development Center, Indonesian National Institute of Aeronautics and Space (LAPAN), Bandung 40173, Indonesia.

(Received April 29, 1999; revised August 2, 1999; accepted August 27, 1999.) 